\title{
Glutamate-Stimulated, Guanine Nucleotide-Mediated Phosphoinositide Turnover in Astrocytes Is Inhibited by Cyclic AMP
}

\author{
Patricia L. Robertson, George R. Bruno, and Subhash C. Datta \\ Departments of Pediatrics and Neurology, The University of Michigan, Ann Arbor, Michigan, U.S.A.
}

\begin{abstract}
The potential for cross-talk between the adenyl cyclase and phosphoinositide (PPI) lipid second messenger system was investigated in astrocytes cultured from neonatal rat brain. Glutamate-stimulated PPI turnover, measured by the formation of total inositol phosphates from myo $\left[{ }^{3} \mathrm{H}\right]$ inositol-labeled lipids, was inhibited in a concentrationdependent manner by the elevation of intracellular cyclic AMP levels produced either by stimulation of the isoproterenol receptor linked to adenyl cyclase or by its direct activation by forskolin. $N^{6}, 2^{\prime}-O$-Dibutyryl cyclic AMP, an analogue that can also activate cyclic AMP-dependent kinase, inhibited glutamate-stimulated PPI turnover in a concentration-dependent manner as well, a result suggesting that cyclic AMP-dependent kinase is involved in mediating the inhibition. Inclusion of an inhibitor of cyclic AMP-dependent kinase, 1-(5-isoquinolinesulfonyl)-2 methylpiperazine dihydrochloride or $\mathrm{N}$-(2-guanidinoethyl)-5-isoquinolinesulfonamide hydrochloride, blocked the cyclic AMP-mediated inhibition in a concentration-dependent manner, a finding further supporting this hypothesis. The site of inhibition of the phosphoinositol lipid pathway by cyclic AMP was probed
\end{abstract}

using a digitonin-permeabilized cell system. Guanosine $5^{\prime}-$ $O$-(3-thiotriphosphate), a nonhydrolyzable analogue of GTP, stimulated PPI turnover and potentiated glutamate-stimulated PPI turnover, and guanosine $5^{\prime}-O$-(3-thiodiphosphate) inhibited glutamate-stimulated PPI turnover in these cells, results providing evidence that glutamate receptors are coupled to phospholipase $\mathrm{C}$ by a guanine nucleotide binding protein in astrocytes. $N^{6}, 2^{\prime}-O$-Dibutyryl cyclic AMP and agents that elevate cyclic AMP levels inhibited the PPI turnover stimulated by guanosine 5 - $O$-(3-thiotriphosphate), as well as that potentiated by guanosine $5^{\prime}-O$-(3-thiotriphosphate) in the presence of glutamate, results suggesting that the cyclic AMP-dependent inhibition occurs at or distal to the putative guanine nucleotide binding protein. Because basal PPI turnover was not altered by elevation of cyclic AMP levels, direct inhibition of phospholipase $\mathrm{C}$ is unlikely. Key Words: Glutamate-Adenyl cyclase-Cyclic AMP-Phosphoinositides-GTP binding protein. Robertson P. L. et al. Glutamate-stimulated, guanine nucleotide-mediated phosphoinositide turnover in astrocytes is inhibited by cyclic AMP. J. Neurochem. 55, 1727-1733 (1990).
Evidence is accumulating that astrocytes are important in controlling the chemical environment of the brain. This regulation appears to be mediated, at least in part, by direct interaction of neurotransmitters and trophic factors with glial membranes, leading to various cellular responses, including ion transport, neurotransmitter uptake and release, and changes in membrane potential (Drejer et al., 1982; Kettenmann and Schachner, 1985; Kimelberg et al., 1986; Shain et al., 1986). The excitatory amino acid glutamate is a neurotransmitter that may play such a role.
Glutamate can directly depolarize the membranes of astrocytes in culture (Bowman and Kimelberg, 1984; Kettenmann and Schachner, 1985), and the coupling of glutamate to the receptor-activated phosphoinositide (PPI) lipid second messenger system was demonstrated by Pearce et al. (1986a) in studies where glutamate stimulated the formation of inositol phosphates (IPs) from PPI lipids.

Astrocytes also possess receptors that are coupled to the regulation of adenyl cyclase and production of cyclic AMP, the other major cellular signal transduc-
Received December 11, 1989; revised manuscript received April 17, 1990; accepted May 1, 1990.

Address correspondence and reprint requests to Dr. P. L. Robertson at Section of Pediatric Neurology, University of Michigan Medical School, R6060 Kresge II, Box 0570 Ann Arbor, MI 48109-0570, U.S.A.

Abbreviations used: A-kinase, cyclic AMP-dependent kinase; dBcAMP, $N^{6}, 2^{\prime}-O$-dibutyryl cyclic AMP; carbachol, carbamylcholine chloride; DMEM, Dulbecco's modified Eagle's medium; GDP $\beta$ S guanosine 5'-O-(3-thiodiphosphate); $\mathrm{G}_{\mathrm{p}}$ protein, GTP binding protein; GTP[S], guanosine 5'-O-(3-thiotriphosphate); H-7, 1-(5-isoquinolinesulfonyl)-2-methylpiperazine dihydrochloride; HA-1004, N-(2guanidinoethyl-5-isoquinolinesulfonamide hydrochloride; IP, inositol phosphate; $\mathbf{I P}_{1}, \mathbf{I P}_{2}$, and $\mathrm{IP}_{3}$, inositol mono-, bis-, and trisphosphate, respectively; PPI, phosphoinositide. 
tion pathway (McCarthy and de Vellis, 1978; Henn and Henn, 1980; Van Calker et al., 1983; Evans et al., 1984). Best studied of these is the $\beta$-adrenergic receptor, which may be involved in the metabolism of glial glycogen, important in the regulation of CNS energy stores (Cummins et al., 1983).

Recent evidence indicates that these two second messenger systems can play interconnected roles in mediating cellular behavior, although their mutual influences vary widely among different cells and tissues (Kaibuchi et al., 1982; Francel et al., 1987; Hill and Kendall, 1987; Madison and Brown, 1988; Laufer and Changeux, 1989). Defining the nature and molecular mechanisms of such potential cross-talk is important for understanding the ultimate functional responses of cells.

Therefore, the present study was undertaken to investigate the influence of cyclic AMP on glutamatestimulated PPI lipid turnover in cultured neonatal rat astrocytes. Our results indicate that the elevation of intracellular cyclic AMP levels, either by receptorstimulated or direct activation of adenyl cyclase, resulted in dose-dependent inhibition of glutamate-stimulated PPI lipid hydrolysis in these cells. $N^{6}, 2^{\prime}-O$-Dibutyryl cyclic AMP (dBcAMP), an analogue that, like cyclic AMP, activates cyclic AMP-dependent kinase (A-kinase), also inhibited glutamate-stimulated PPI turnover, a result suggesting that this pathway, probably through A-kinase-directed phosphorylations, is involved in mediating the inhibition by all of these agents.

A digitonin-permeabilized cell system was used to investigate the mechanism by which stimulation of the glutamate receptors is linked to phospholipase $\mathrm{C}$ and PPI hydrolysis in astrocytes. We found that guanosine 5'-O-(3-thiotriphosphate) (GTP[S]), a nonhydrolyzable analogue of GTP, stimulated the formation of ${ }^{3} \mathrm{H}-\mathrm{IP}$ from $m y o-\left[{ }^{3} \mathrm{H}\right]$ inositol-prelabeled PPI lipids and potentiated the PPI turnover stimulated by glutamate, as well, a finding providing evidence that glutamate receptors are coupled to phospholipase $C$ by a GTP binding protein $\left(\mathrm{G}_{\mathrm{p}}\right.$ protein).

In the permeabilized astrocytes, isoproterenol, forskolin, and dBcAMP, each inhibited the formation of ${ }^{3} \mathrm{H}$-IP stimulated by GTP[S], as well as the ${ }^{3} \mathrm{H}$-IP formation stimulated by glutamate and potentiated by GTP[S]. These data suggest that elevation of cyclic AMP levels inhibits glutamate-stimulated PPI hydrolysis by interfering at or distal to the $G_{p}$ protein that links the glutamate receptor to phospholipase $\mathrm{C}$ in astrocytes.

\section{MATERIALS AND METHODS}

\section{Materials}

myo- $\left[2 \cdot{ }^{3} \mathrm{H}\right]$ Inositol $(15 \mathrm{Ci} / \mathrm{mmol})$ was obtained from American Radiolabeled Chemicals (St. Louis, MO, U.S.A.). L-Isoproterenol, forskolin, GTP[S], dBcAMP, digitonin, bradykinin, carbamylcholine chloride (carbachol), and 1-(5-isoquinolinesulfonyl)-2 methylpiperazine dihydrochloride ( $\mathrm{H}-$ 7) were obtained from Sigma Chemical Co. (St. Louis).
$N$-(2-Guanidinoethyl)-5-isoquinolinesulfonamide hydrochloride (HA-1004) was obtained from Seikagaku America (St. Petersburg, FL, U.S.A.). Guanosine 5'-O-(3-thiodiphosphate) (GDP $\beta S$ ) and neutral Dispase were obtained from Boehringer-Mannheim (Indianapolis, IN, U.S.A.). Dowex AG 1-8X resin (formate form) was obtained from BioRad Laboratories (Richmond, CA, U.S.A.). Fluo-3 was obtained from Molecular Probes (Eugene, OR, U.S.A.). Tissue culture supplies were obtained from Co-star. Dulbecco's modified Eagle's medium (DMEM) was obtained from GIBCO (Grand Island, NY, U.S.A.). Defined fetal bovine serum was obtained from Hyclone (Logan, UT, U.S.A.).

\section{Cell culture}

Astrocyte cultures were prepared from neonatal rat brain according to a modification of a previously described method (Frangakis and Kimelberg, 1984; Robertson and Goldstein, 1988). The cells were used at confluence, 7-10 days after first passage, and were $90-95 \%$ positive on immunocytochemical staining for glial fibrillary acidic protein, a specific astrocyte marker.

\section{Measurement of PPI turnover}

Intact cells. Intact, confluent, first-passage astrocyte cultures in six-well multiplates were prelabeled for $48 \mathrm{~h}$ with $10 \mu \mathrm{Ci}$ of $m y a-\left[2{ }^{3} \mathrm{H}\right]$ inositol $(15 \mathrm{Ci} / \mathrm{mmol})$ in $1 \mathrm{ml}$ of serum-free DMEM. Inositol-free medium was not used for the prelabeling as described previously (Robertson et al., 1988), because no significant difference in labeling was found using DMEM containing inositol. Labeling medium was removed, and the cells were incubated with various agents and $5 \mathrm{mM}$ $\mathrm{LiCl}$, in a final volume of $1 \mathrm{ml}$ of DMEM, at $37^{\circ} \mathrm{C}$ usually for $10 \mathrm{~min}$. Reactions were stopped by addition of $1 \mathrm{ml}$ of $10 \%$ cold trichloroacetic acid to the wells, after which the cells were scraped into the medium. The cell suspension was centrifuged, and the deproteinized supernatant was washed six times, each with $3 \mathrm{ml}$ of water-saturated ether, and neutralized with $1 M \mathrm{KHCO}_{3}$. The total IP fraction was separated and quantified by ion exchange chromatography as previously described (Robertson et al., 1988). In several experiments, individual ${ }^{3} \mathrm{H}-\mathrm{IPs}-\left[{ }^{3} \mathrm{H}\right]$ inositol monophosphate $\left(\left[{ }^{3} \mathrm{H}\right] I \mathrm{P}_{1}\right),\left[{ }^{3} \mathrm{H}\right]$ inositol bisphosphate $\left(\left[{ }^{3} \mathrm{H}\right]\left[\mathrm{P}_{2}\right)\right.$, and $\left[{ }^{3} \mathrm{H}\right]-$ inositol trisphosphate $\left(\left[{ }^{3} \mathrm{H}\right] \mathrm{I}_{3}\right)$-were fractionated by ion exchange chromatography as described elsewhere (Robertson et al., manuscript in preparation).

Permeabilized cells. After the period of prelabeling with myo- $\left[{ }^{3} \mathrm{H}\right]$ inositol, intact cells in multiwells were permeabilized by a modification of a procedure described by Eberhard and Holz (1987). After a 10-min incubation with $1 \mathrm{ml}$ of a buffer containing $139 \mathrm{~m} M$ potassium monophosphate, $2 \mathrm{~m} M$ ATP, $4 \mathrm{~m} M \mathrm{MgCl}_{2}, 5 \mathrm{~m} M \mathrm{LiCl}, 10 \mathrm{~m} M$ EGTA, $20 \mu M$ digitonin, and $30 \mathrm{~m} M$ sodium HEPES ( $\mathrm{pH} 7.4$ at $37^{\circ} \mathrm{C}$ ), the cells were rinsed twice with the same buffer minus digitonin and containing concentrations of $\mathrm{CaCl}_{2}$ to achieve $\mathrm{Ca}^{2+} /$ EGTA molar ratios between 0.0 and 5.5 for the experiments determining the $\mathrm{Ca}^{2+}$ sensitivity of the agonists. In the other experiments, the $\mathrm{Ca}^{2+} /$ EGTA ratio was maintained at 0.5 (corresponding to $800 \mathrm{n} M$ free $\left.\mathrm{Ca}^{2+}\right)$. Free $\mathrm{Ca}^{2+}$ concentrations in the various buffers were determined fluorometrically with fluo- 3 as the indicator.

After incubation at $37^{\circ} \mathrm{C}$ for the indicated times (usually $30 \mathrm{~min}$ ) in the same $\mathrm{Ca}^{2+}$-containing buffer with agonists, the release of total ${ }^{3} \mathrm{H}$-IPs was measured by addition of $1 \mathrm{ml}$ of ice-cold $10 \%$ trichloroacetic acid to the medium, which had been rapidly removed from the wells. Extraction, sepa- 
ration, and quantification of the phosphates were performed in the same way as for the intact cells. In experiments where the effects of dBcAMP, isoproterenol, or forskolin on PPI turnover were being measured, the prelabeled cells were incubated with these agents for $10 \mathrm{~min}$ at $37^{\circ} \mathrm{C}$ before permeabilization. Release of labeled phosphates was then measured after permeabilization and incubation with the agonists. In some experiments, the inhibitory agents were added after the cells had been permeabilized, simultaneously with the agonists. After permeabilization, the cells had a normal appearance by light microscopy, which was maintained throughout the period of stimulation by agonist.

\section{RESULTS}

In astrocytes prelabeled with $m y o-\left[{ }^{3} \mathrm{H}\right]$ inositol and permeabilized with digitonin, glutamate or glutamate plus $100 \mu M$ GTP[S] combined each stimulated a concentration-dependent release of ${ }^{3} \mathrm{H}$-IP (Fig. 1). Total ${ }^{3} \mathrm{H}$-IP content was measured in all experiments after it had been determined that the glutamate-stimulated increase in ${ }^{3} \mathrm{H}$-IP at 10 and 30 min was predominantly present as [ $\left.{ }^{3} \mathrm{H}\right] \mathrm{IP} \mathrm{P}_{1}(72$ and $81 \%$, respectively) and the rest as either $\left[{ }^{3} \mathrm{H}\right] I \mathrm{P}_{2}(20$ and $15 \%)$ or $\left[{ }^{3} \mathrm{H}\right] \mathrm{IP}_{3}(8$ and $4 \%$ ), with no significant increase in the glycerophosphoinositol fraction (data not shown). Although GTP[S] increased the maximal amount of ${ }^{3} \mathrm{H}$-IP released on stimulation by each concentration of glutamate, it did not displace the curve that describes the concentration dependence of glutamate-stimulated ${ }^{3} \mathrm{H}$ IP release, a result suggesting that GTP[S] does not alter the binding characteristics of glutamate to its re-

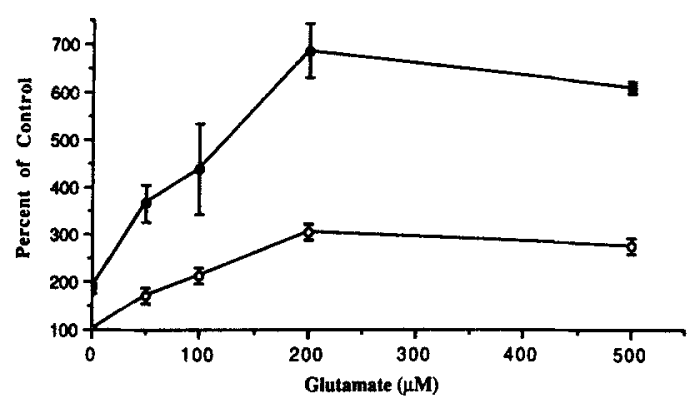

FIG. 1. Dose dependence of glutamate- and glutamate plus GTP[S]-stimulated ${ }^{3} \mathrm{H}$-IP release in permeabilized astrocytes. Cells were prelabeled with myo- $\left[{ }^{3} \mathrm{H}\right]$ inositol, permeabilized with digitonin, and incubated for $30 \mathrm{~min}$ at $37^{\circ} \mathrm{C}$ with the indicated concentrations of glutamate in the presence ( $)$ ) or absence (O) of $100 \mu M$ GTP[S]. GTP[S] at $100 \mu M$ was previously determined to be the concentration that independently stimulated maximal ${ }^{3} \mathrm{H}-\mathrm{IP}$ release (data not shown). Data are mean \pm SEM (bars) values of triplicate samples; where no bars are shown, the SEM was $\leq 2 \%$ of the mean. Essentially identical results were obtained in four independent experiments. The synergism of glutamate plus GTP[S], expressed as the percent stimulation that is greater than additive for glutamate and GTP[S] stimulating independently, is calculated by the formula $\left([A-(B+C] / A) \times 100\right.$, where $A$ is the ${ }^{3} \mathrm{H}-\mathrm{IP}$ release $(\mathrm{dpm})$ in the presence of glutamate plus GTP[S] minus control, $B$ is the ${ }^{3} \mathrm{H}-\mathrm{IP}$ release (dpm) in the presence of glutamate alone minus control, and $C$ is the ${ }^{3} \mathrm{H}-\mathrm{IP}$ release (dpm) in the presence of GTPIS] alone minus control. The percent stimulation for glutamate concentrations of $50,100,200$, and $500 \mu M$ was $54,55,51$, and $52 \%$, respectively.

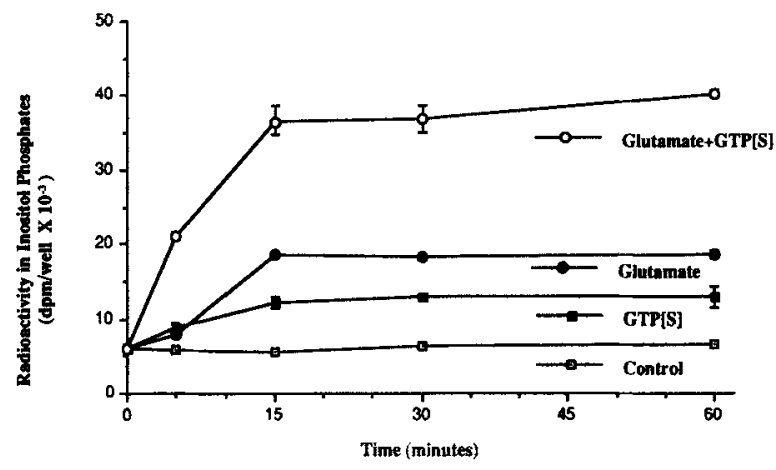

FIG. 2. Time course of the effects of glutamate, GTP[S], and glutamate plus GTP[S] on ${ }^{3} \mathrm{H}$-IP formation in permeabilized first-passage astrocytes. Cells prelabeled with myo- $\left[{ }^{3} \mathrm{H}\right]$ inositol were permeabilized with digitonin and incubated at $37^{\circ} \mathrm{C}$ with $100 \mu \mathrm{M}$ GTP[S], $200 \mu \mathrm{M}$ glutamate, or both. The incubations were terminated at the times indicated as described in Materials and Methods. Data are mean \pm SEM (bars) values for triplicate samples. Similar results were obtained in three independent experiments.

ceptor. Exposure of the astrocytes to GTP[S] or to glutamate plus GTP[S] in the absence of digitonin stimulated a small amount of ${ }^{3} \mathrm{H}$-IP release, $<30 \%$ of that detected in the presence of digitonin.

Figure 2 illustrates the time course of the effects of maximally effective concentrations of glutamate, GTP[S], and glutamate plus GTP[S]. The stimulation was detectable at $5 \mathrm{~min}$ and plateaued between 15 and $60 \mathrm{~min}$. GTP[S] potentiated the stimulation by glutamate at each time point. The time course of glutamate-stimulated ${ }^{3} \mathrm{H}-\mathrm{IP}$ formation in intact cells also plateaued at 10-15 min (data not shown).

GDP $\beta S$ is a metabolically stable analogue of GDP that has been used extensively as a competitive antagonist of guanine nucleotide binding protein activation (Eckstein et al., 1979; Brass et al., 1986). Addition of GDP $\beta S$ to astrocytes made permeable by digitonin inhibited the glutamate-stimulated release of ${ }^{3} \mathrm{H}$-IP (Fig. $3)$. The $K_{\mathrm{i}}(1.47 \mathrm{~m} M)$ for this inhibition of glutamatestimulated ${ }^{3} \mathrm{H}$-IP release by GDP $\beta S$ was very close to that for inhibition of ${ }^{3} \mathrm{H}$-IP release stimulated by GTP[S] $(1.35 \mathrm{mM})$.

The potential role of free $\mathrm{Ca}^{2+}$ in the regulation of phospholipase $\mathrm{C}$ was assessed in permeabilized astrocytes. Raising the free $\mathrm{Ca}^{2+}$ concentration from $<10$ to $800 \mathrm{n} M$ resulted in a modest (160\% of control values) increase in ${ }^{3} \mathrm{H}$-IP release (Fig. 4). Glutamate and GTP[S] further potentiated this $\mathrm{Ca}^{2+}$-dependent release of ${ }^{3} \mathrm{H}-\mathrm{IP}$ to 300 and $197 \%$ of control values at $800 \mathrm{nM}$ $\mathrm{Ca}^{2+}$. Glutamate and GTP[S] together elicited a synergistic increase in PPI hydrolysis that was also maximal at $800 \mathrm{n} M(630 \%$ of control values), although the synergism, expressed as the percent stimulation greater than additive (see legend of Fig. 1), was approximately the same at concentrations of free $\mathrm{Ca}^{2+}$ between 14 and $800 \mathrm{n} M$.

Other agonists that have been linked to PPI hydrolysis in astrocytes (Pearce et al., 1986b; Ritchie et al., 


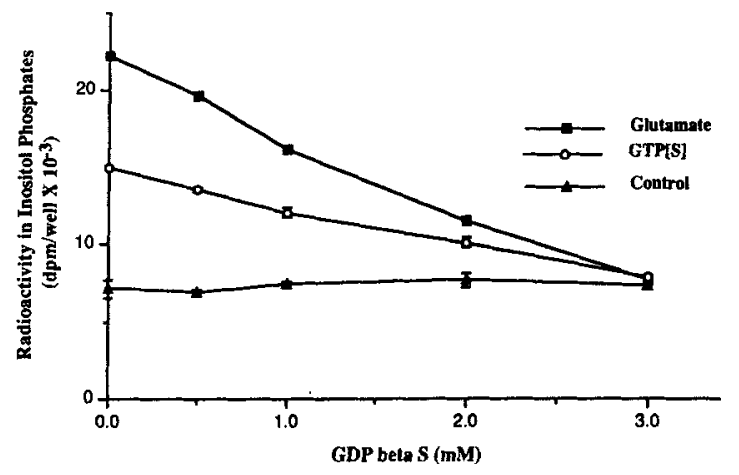

FIG. 3. Inhibition of glutamate-stimulated ${ }^{3} \mathrm{H}-\mathrm{IP}$ formation by GDP $\beta S$. Confluent first-passage astrocytes were prelabeled with myo- $\left[{ }^{3} \mathrm{H}\right]$ inositol, permeabilized with digitonin, and incubated for $30 \mathrm{~min}$ at $37^{\circ} \mathrm{C}$ with $200 \mu \mathrm{M}$ glutamate, $100 \mu \mathrm{M}$ GTP[S], or neither in the presence of the indicated concentrations of GDPBS. Data are mean \pm SEM (bars) values for triplicate samples; where no bars are shown, the SEM was $\leq 2 \%$ of the mean. Essentially identical results were obtained in two independent experiments.

1987) were also evaluated for their effect on permeabilized astrocytes in the presence or absence of GTP[S]. The effects of bradykinin and carbachol, at concentrations that independently stimulated maximal ${ }^{3} \mathrm{H}-\mathrm{IP}$ formation, were potentiated by GTP[S], although to a lesser degree than that stimulated by glutamate (Fig. 5). These results are consistent with the potentiation of GTP[S]-stimulated PPI turnover by carbachol in astrocyte membranes (Pearce et al., 1988).

Isoproterenol, a $\beta$-adrenergic agonist that activates adenyl cyclase and elevates intracellular cyclic AMP levels in astrocytes, caused a concentration-dependent inhibition of glutamate-stimulated ${ }^{3} \mathrm{H}-\mathrm{IP}$ accumulation in myo- $\left[{ }^{3} \mathrm{H}\right]$ inositol-prelabeled astrocytes $\left(K_{\mathrm{i}}=49 \mu M\right)$.

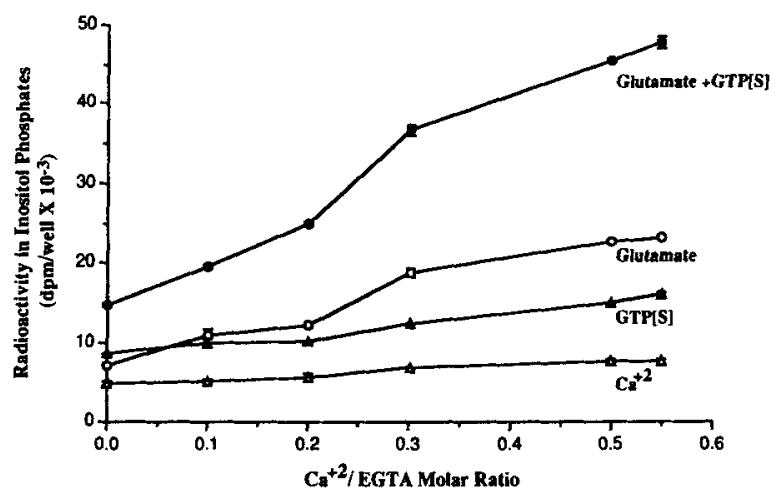

FIG. 4. Effect of free $\mathrm{Ca}^{2+}$ on release of ${ }^{3} \mathrm{H}-\mathrm{IPS}$ from permeabilized astrocytes. Cells prelabeled with $m y o-\left[{ }^{3} \mathrm{H}\right]$ inositol were permeabilized and incubated for $30 \mathrm{~min}$ in buffer with $\mathrm{CaCl}_{2}$ added to achieve the indicated $\mathrm{Ca}^{2+} /$ EGTA molar ratios and with $200 \mu \mathrm{M}$ glutamate, $100 \mu M$ GTP[S], $200 \mu M$ glutamate plus GTP[S], or neither. Data are mean \pm SEM (bars) values of triplicate samples. Essentially identical results were obtained in two independent experiments. Free $\mathrm{Ca}^{2+}$ concentrations of $<10,14,39,101,800$, and $5,450 \mathrm{nM}$ were obtained at $\mathrm{Ca}^{2+} /$ EGTA molar ratios of $0,0.1,0.2,0.3,0.5$, and 0.55 , respectively, with EGTA maintained at a concentration of $10 \mathrm{mM}$.

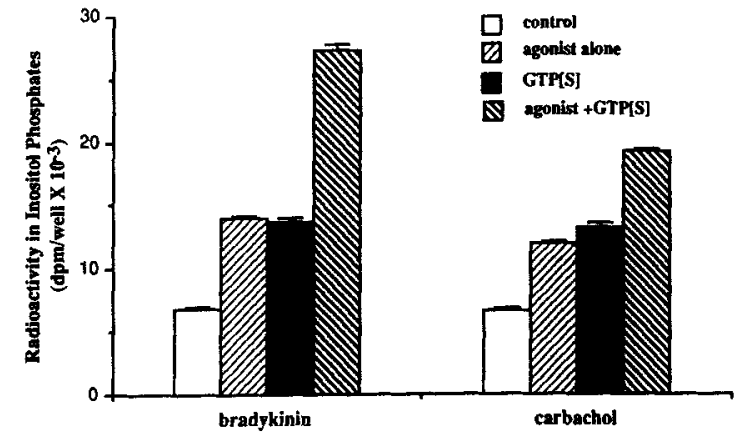

FIG. 5. Effects of bradykinin, carbachol, and GTP[S] on ${ }^{3} \mathrm{H}-\mathrm{IP}$ release in permeabilized astrocytes. Cells were prelabeled with myo$\left[{ }^{3} \mathrm{H}\right]$ inositol, permeabilized with digitonin, and incubated for $30 \mathrm{~min}$ at $37^{\circ} \mathrm{C}$ with $200 \mu \mathrm{M}$ bradykinin, $500 \mu \mathrm{M}$ carbachol, $100 \mu \mathrm{M}$ GTP[S], the combination of either agonist plus GTP[S], or neither. Data are mean \pm SEM (bars) values of triplicate samples. Essentially identical results were obtained in three independent experiments. The synergism of bradykinin plus GTP[S], expressed as the percent stimulation that was greater than additive for each agent individually, was $33 \pm 4 \%$, and that of carbachol plus GTP[S] was 7 $\pm 3 \%$.

Basal levels of ${ }^{3} \mathrm{H}$-IP accumulation were not affected by isoproterenol. Although isoproterenol decreased the maximal production of ${ }^{3} \mathrm{H}$-IP stimulated by glutamate, the concentration of glutamate required to produce half-maximal ${ }^{3} \mathrm{H}$-IP accumulation did not change significantly (Fig. 6).

Testing other A-kinase-activating agents, we found that forskolin at concentrations between 10 and 100 $\mu M$ and $\mathrm{dBcAMP}$ at concentrations between 10 and $500 \mu M$ each inhibited the ability of glutamate to stimulate ${ }^{3} \mathrm{H}$-IP accumulation in a concentration-dependent manner (Table 1). Basal ${ }^{3} \mathrm{H}$-IP formation was not inhibited by either of these agents. Inclusion of the protein kinase inhibitors HA-1004 or H-7 in the medium (Hidaka et al., 1984; Yada et al., 1989) each significantly reduced the inhibition of glutamate-stimu-

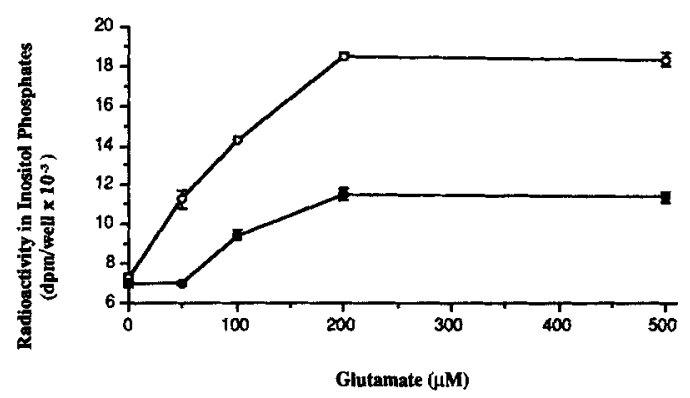

FIG. 6. Effect of isoproterenol on concentration dependence of glutamate-stimulated ${ }^{3} \mathrm{H}$-IP formation. First-passage astrocyte cultures prelabeled with myo- $\left[^{3} \mathrm{H}\right]$ inositol were incubated for 10 min at $37^{\circ} \mathrm{C}$ with glutamate at the concentrations indicated, in the presence $(\Theta)$ or absence $(O)$ of $100 \mu M$ isoproterenol. Data are mean \pm SEM (bars) values for triplicate samples. Essentially identical results were obtained in two independent experiments. $E_{50}$ values for glutamate in the presence or absence of isoproterenol were 85 and $110 \mu M$, respectively. 
TABLE 1. Effects of forskolin and $d B C A M P$ on glutamate-stimulated ${ }^{3} \mathrm{H}-\mathrm{IP}$ formation

\begin{tabular}{cc}
\hline Inhibitor & Percent inhibition \\
\hline Forskolin & \\
$10 \mu M$ & $20 \pm 2 \%$ \\
$50 \mu M$ & $66 \pm 3 \%$ \\
$100 \mu M$ & $95 \pm 4 \%$ \\
dBcAMP & \\
$10 \mu M$ & $18 \pm 3 \%$ \\
$100 \mu M$ & $57 \pm 2 \%$ \\
$500 \mu M$ & $100 \pm 1 \%$ \\
\hline
\end{tabular}

First-passage astrocytes prelabeled for $48 \mathrm{~h}$ with $m y a-\left[{ }^{3} \mathrm{H}\right]$ inositol were incubated for $10 \mathrm{~min}$ at $37^{\circ} \mathrm{C}$ with $200 \mu \mathrm{M}$ glutamate in the presence or absence of forskolin or DBcAMP at the indicated concentrations. The results are expressed as the percent inhibition of glutamate-stimulated ${ }^{3} \mathrm{H}$-IP formation in the absence of inhibitors and are mean $\pm S E M$ values for two separate experiments. In these experiments, basal and glutamate-stimulated ${ }^{3} \mathrm{H}-\mathrm{IP}$ accumulations in the absence of inhibitors were $6.36 \pm 0.69$ and $17.47 \pm 0.67 \times 10^{3}$ $\mathrm{dpm} /$ well, respectively. Basal ${ }^{3} \mathrm{H}$-IP accumulation was not affected by the inhibitors.

lated PPI hydrolysis by dBcAMP in a concentrationdependent manner with $K_{\mathrm{i}}$ values of 0.45 and $1.0 \mu M$, respectively.

To investigate the site at which cyclic AMP inhibits PPI hydrolysis, astrocytes were first exposed to dBcAMP for $10 \mathrm{~min}$, then permeabilized with digitonin, and exposed to agonists. This exposure to dBcAMP resulted in a concentration-dependent inhibition of ${ }^{3} \mathrm{H}$-IP release from the permeabilized cells on stimulation by GTP[S] as well as by glutamate plus GTP[S] (Fig. 7). dBcAMP also inhibited glutamateand glutamate plus GTP[S]-stimulated ${ }^{3} \mathrm{H}$-IP release when it was added simultaneously with the agonist after permeabilization of the cells $(85-95 \%$ of the inhibition observed in the pretreated cells; data not shown).

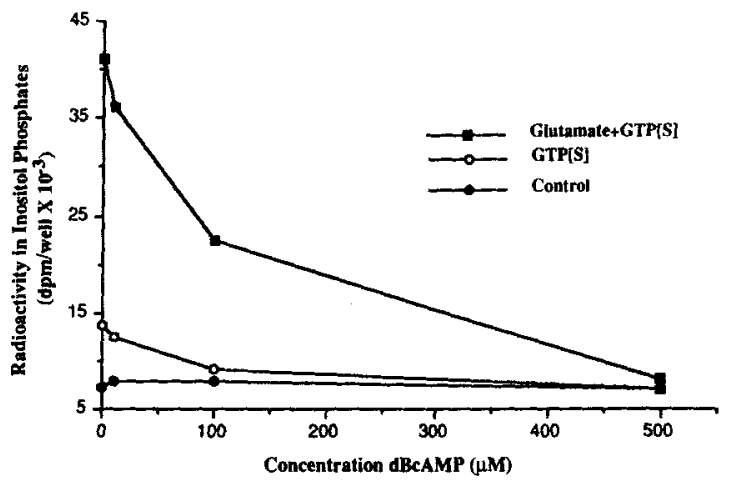

FIG. 7. Effect of dBCAMP on GTP[S]-mediated ${ }^{3} \mathrm{H}-\mathrm{IP}$ formation in permeabilized astrocytes. Cells prelabeled with myo- $\left[{ }^{3} \mathrm{H}\right]$ inositol were exposed to various concentrations of dBcAMP for $10 \mathrm{~min}$. The cells were permeabilized with digitonin and then incubated for $30 \mathrm{~min}$ at $37^{\circ} \mathrm{C}$ with $100 \mu \mathrm{M}$ GTP[S] or with $200 \mu M$ giutamate plus $100 \mu M$ GTP[S]. Data are mean \pm SEM (bars) values for triplicate samples. Essentially identical results were obtained in three independent experiments.
Pretreatment for $10 \mathrm{~min}$ with $100 \mu \mathrm{M}$ isoproterenol or $100 \mu M$ forskolin inhibited ${ }^{3} \mathrm{H}-\mathrm{IP}$ release by glutamate, GTP[S], or glutamate plus GTP[S] in the permeabilized cells as well (Fig. 8). As with the inhibition produced by $\mathrm{dBcAMP}$ in the permeabilized cells, isoproterenol and forskolin did not affect basal ${ }^{3} \mathrm{H}$-IP formation. Nor did dBcAMP, forskolin, or isoproterenol inhibit the modest release of ${ }^{3} \mathrm{H}$-IP produced by elevating the $\mathrm{Ca}^{2+}$ concentration alone (data not shown).

However, in the permeabilized cells, ${ }^{3} \mathrm{H}$-IP release stimulated by bradykinin, by carbachol, or by either in combination with GTP[S] was inhibited by isoproterenol, forskolin, and dBcAMP (data not shown).

\section{DISCUSSION}

Two principal findings resulted from the present study. First, in a permeabilized cell system, we found evidence to support the proposal that a $G_{p}$ protein mediates the metabolism of PPI lipids in astrocytes and that glutamate-stimulated PPI hydrolysis is mediated through this $G_{p}$ protein and is dependent on the concentration of free $\mathrm{Ca}^{2+}$. Second, we determined that the inhibition of glutamate-stimulated PPI hydrolysis by agents that elevate cyclic AMP levels or by analogues capable of activating A-kinase appears to occur at a postreceptor site, at or distal to this $G_{p}$ protein.

Stimulation of the release of ${ }^{3} \mathrm{H}$-IP by GTP[S] alone in permeabilized astrocytes suggests involvement of the $\mathrm{G}_{\mathrm{p}}$ protein in the signal transduction process (Cockcroft and Gomperts, 1985). The coupling of glutamate receptors to phospholipase $C$ by this putative $G_{p}$ protein is supported both by the synergistic stimulation of ${ }^{3} \mathrm{H}$ IP formation in the combined presence of glutamate and GTP[S] and by the inhibition of glutamate-stimulated PPI hydrolysis by GDP $\beta$ S at virtually the same $K_{\mathrm{i}}$ as it inhibits GTP[S]-stimulated PPI turnover (Fig. 3 ). The inhibition by GDP $\beta$ S suggests that guanine

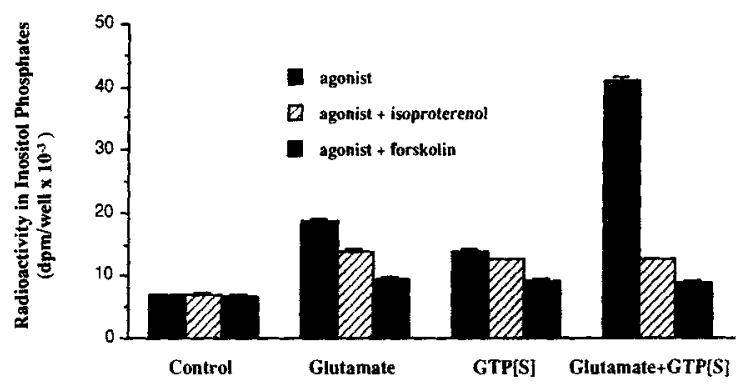

FIG. 8. Effects of isoproterenol and forskolin on glutamate-, GTP[S]-, and glutamate plus GTP[S]-stimulated ${ }^{3} \mathrm{H}$-IP formation. First-passage astrocytes prelabeled with myo- $\left[{ }^{3} \mathrm{H}\right]$ inositol were exposed to $100 \mu \mathrm{M}$ isoproterenol or $100 \mu \mathrm{M}$ forskolin for $10 \mathrm{~min}$. They were then permeabilized and incubated at $37^{\circ} \mathrm{C}$ for $30 \mathrm{~min}$ with $200 \mu M$ glutamate, $100 \mu M$ GTP[S], or the combination of both. Data are mean \pm SEM (bars) values for triplicate samples. Essentially identical results were obtained in three independent experiments. 
nucleotides remain in astrocytes after permeabilization and are necessary for the receptor-stimulated hydrolysis of PPI lipids by glutamate mediated through $a \mathrm{G}_{\mathrm{p}}$ protein.

Glutamate-stimulated, $G_{p}$ protein-mediated phospholipase $\mathrm{C}$ activity in astrocytes is also sensitive to the concentration of free $\mathrm{Ca}^{2+}$ (Fig. 4). Significant enhancement of PPI hydrolysis in the combined presence of glutamate and GTP[S] occurred at free $\mathrm{Ca}^{2+}$ concentrations as low as 14-39 $\mathrm{nM}$, a result supporting the proposal that a $G_{p}$ protein could potentiate glutamate-stimulated signal transduction at concentrations of $\mathrm{Ca}^{2+}$ likely to be encountered in quiescent cells. Potentiation was greatest, however, at higher concentrations of $\mathrm{Ca}^{2+}$. Moreover, Pearce et al. (1986a) showed in ${ }^{45} \mathrm{Ca}^{2+}$ efflux studies that the intracellular $\mathrm{Ca}^{2+}$ concentration probably does rise in astrocytes on stimulation by glutamate and that PPI turnover is partially dependent on extracellular calcium, a finding suggesting that the elevation of $\mathrm{Ca}^{2+}$ level above basal values plays some role in phospholipase $\mathrm{C}$ activation in astrocytes. To what concentration free $\mathrm{Ca}^{2+}$ actually rises and influences $G_{p}$ protein-mediated phospholipase $C$ activity in intact astrocytes, however, remains to be determined.

Glutamate-stimulated ${ }^{3} \mathrm{H}$-IP formation in astrocytes is inhibited by $\beta$-adrenergic receptor stimulation (Fig. 6 ), which elevates cyclic AMP levels in astrocytes (McCarthy and de Vellis, 1978); by forskolin (Table 1), a diterpene that directly activates adenyl cyclase (Seamon and Daly, 1986); and by the cyclic AMP analogue dBcAMP (Table 1). Thus, activation of A-kinase, which occurs with all of these agents, seems likely to be the critical step in mediating the inhibition and is in agreement with the inhibition of PPI turnover on elevation of cyclic AMP levels by various mechanisms in other cellular systems (Takenawa et al., 1986; Francel et al., 1987; Paris and Pouyssegur, 1987; Puurunen et al., 1987; Ritchie et al., 1987; Guillon et al., 1988; Madison and Brown, 1988; Windebank et al., 1988; Akil and Fisher, 1989; Yada et al., 1989).

Moreover, the effect of dBcAMP, isoproterenol, or forskolin on glutamate-stimulated PPI turnover was prevented in the presence of the protein kinase inhibitors HA-1004 and H-7. A complete block of the cyclic AMP-mediated inhibition by HA-1004 at a concentration $(3 \mu M)$ well below its $K_{\mathrm{i}}$ for protein kinase C $(40 \mu M)$ (Hidaka et al., 1984) further supports the proposal that the cyclic AMP-mediated inhibition occurs through an A-kinase dependent mechanism, consistent with a similar response of platelets (Yada et al., 1989).

Several findings of the present study provide evidence that localizes the point in the PPI pathway at which the cyclic AMP-dependent mechanisms might interfere. The concentration of glutamate required to produce half-maximal stimulation was not significantly altered by isoproterenol (Fig. 6), a finding indicating that cyclic AMP-mediated inhibition does not change the agonist's affinity for its receptor.
Moreover, in the permeabilized astrocytes, $\mathrm{dBcAMP}$, isoproterenol, and forskolin each inhibited postreceptor GTP[S]-stimulated PPI hydrolysis, as well as the stimulation potentiated by GTP[S] in the presence of glutamate (Figs. 7 and 8). These results point to the $G_{p}$ protein or its interaction with phospholipase $\mathrm{C}$ as the site of inhibition by cyclic AMP, rather than at the receptor or its coupling to the $G_{p}$ protein. Our results do not eliminate the possibility that cyclic AMP could also affect glutamate receptor number but preclude that inhibition could occur exclusively by this mechanism, because GTP[S]-stimulated ${ }^{3} \mathrm{H}$-IP release, which bypasses the receptor, was inhibited. Consistent with our findings, postreceptor sites of inhibition were suggested by other studies, as well, in platelets (Lazarowski and Lapetina, 1989; Yada et al., 1989) and in SK-N-SH neuroblastoma cells (Akil and Fisher, 1989).

This study did not identify the specific A-kinase substrate(s) that might inhibit PPI turnover in astrocytes. The $G_{p}$ protein itself is a possibility, as are enzymes that regulate the availability of substrates for hydrolysis by phospholipase $\mathrm{C}$. Phosphorylation of phospholipase $C$ seems unlikely in our cells, because neither the agents elevating cyclic AMP levels nor dBcAMP inhibited basal ${ }^{3} \mathrm{H}$-IP formation in intact or in permeabilized astrocytes. This is unlike conclusions in $\mathrm{C}_{6} \mathrm{Bu} 1$ cells, in which 8-bromo cyclic AMP modestly inhibited both basal and agonist-stimulated ${ }^{3} \mathrm{H}$-IP formation simultaneously with phosphorylation of one isoenzyme of phospholipase (Kim et al., 1989), a finding suggesting that alteration of phospholipase $C$ could be the inhibitory mechanism in these cells. Moreover, the fact that $\mathrm{dBcAMP}$ and forskolin in astrocytes had no effect on the modest ${ }^{3} \mathrm{H}$-IP release stimulated by increasing the free $\mathrm{Ca}^{2+}$ concentration (data not shown), which presumably activates phospholipase C, makes a direct effect on this enzyme less likely as well.

In summary, our results indicate that elevation of intracellular cyclic AMP levels inhibits PPI lipid hydrolysis in astrocytes and provides evidence that this occurs by an A-kinase-dependent mechanism, acting at or distal to the $G_{p}$ protein linked to phospholipase $C$ activation in these cells. The observation that these effects occur on receptor-stimulated activation of PPI turnover and receptor-stimulated elevation of cyclic AMP levels suggests that this cross-talk could have physiologic relevance to the function of astrocytes in vivo.

Acknowledgment: The authors wish to thank Stephen K. Fisher for helpful comments and for measurements of free $\mathrm{Ca}^{2+}$ levels and Ms. Susan Babbitt for excellent preparation of the manuscript. This work was supported by grant NS 01031-03 from the National Institutes of Health.

\section{REFERENCES}

Akil M. and Fisher S. K. (1989) Muscarinic receptor-stimulated phosphoinositide turnover in human SK-N-SH neuroblastoma cells: differential inhibition by agents that elevate cyclic AMP. J. Neurochem. 53, 1479-1486. 
Bowman C. L. and Kimelberg H. K. (1984) Excitatory amino acids directly depolarize rat brain astrocytes in primary culture. Nature 311, 656-659.

Brass L. F., Laposata M., Banga H. S., and Rittenhouse S. (1986) Regulation of the phosphoinositide hydrolysis pathway by a pertussis toxin-sensitive guanine nucleotide-binding protein. $J$. Biol. Chem. 261, 16838-16847.

Cockeroft S. and Gomperts B. D. (1985) Role of guanine nucleotide binding protein in the activation of phosphoinositide phosphodiesterase. Nature 314, 534-536.

Cummins C. J., Lust W. D., and Passoneau J. V. (1983) Regulation of glycogenolysis in transformed astrocytes in vitro. $J$. Neurochem. 40, 137-144.

Drejer J., Larsson O. M., and Schousboe A. (1982) Characterization of L-glutamate uptake into and release from astrocytes and neurons cultured from different brain regions. Exp. Brain Res. 47, 259-269.

Eberhard D. A. and Holz R. W. (1987) Cholinergic stimulation of inositol phosphate formation in bovine adrenal chromaffin cells: distinct nicotinic and muscarinic mechanisms. $J$. Neurochem. 49, 1634-1643.

Eckstein F., Cassel D., Levkovitz H., Lowe M., and Selinger Z. (1979) Guanosine 5'-O-(2-thiodiphosphate), an inhibitor of adenylate cyclase stimulation by guanine nucleotides and fluoride ions. $J$. Biol. Chem. 254, 9829-9834.

Evans T., McCarthy K. D., and Harden T. K. (1984) Regulation of cyclic AMP accumulation by peptide hormone receptors in immunocytochemically defined astroglial cells. J. Neurochem. 43 , 131-138.

Fisher S. K., Domask L. M., and Roland R. M. (1989) Muscarinic receptor regulation of cytoplasmic $\mathrm{Ca}^{2+}$ concentrations in human SK-N-SH neuroblastoma cells: $\mathrm{Ca}^{2+}$ requirements for phospholipase C activation. Mol. Pharmacol. 35, 195-204.

Francel P. C., Miller R. J., and Dawson G. (1987) Modulation of bradykinin-induced inositol triphosphate release in a novel neuroblastoma dorsal root ganglion sensory neuron cell line. $J$. Neurochem. 48, 1632-1639.

Frangakis M. V. and Kimelberg H. K. (1984) Dissociation of neonatal rat brain by dispase for preparation of primary astrocyte cultures. Neurochem. Res. 9, 1689-1698.

Guillon G., Gallo-Payet N., Balestre M. N., and Lombard C. (1988) Cholera-toxin and corticotropin modulation of inositol phosphate accumulation induced by vasopressin and angiotensin II in rat glomerulosa cells. Biochem. $J$. 253, 765-775.

Henn F. A. and Henn S. W. (1980) The psychopharmacology of astroglial cell. Prog. Neurobiol. 15, 1-17.

Hidaka H., Inagaki M., Kawamoto S., and Sasaki V. (1984) Isoquinoline-sulfonamides, novel and potent inhibitors of cyclic nucleotide dependent protein kinase and protein kinase C. Biochemistry 23, 5036-5041.

Hill S. J. and Kendall D. A. (1987) Studies on the adenosine-receptor mediating the augmentation of histamine-induced inositol phospholipid hydrolysis in guinea-pig cerebral cortex. $B r . J$. Pharmacol. 91, 661-669.

Kaibuchi K., Takai Y., Ogawa Y., Kimura S., and Nishizuka Y. (1982) Inhibitory action of adenosine 3',5'-monophosphate on phosphatidyl-inositol turnover: difference in tissue response. Biochem. Biophys. Res. Commun. 104, 105-112.

Kettenmann H. and Schachner M. (1985) Pharmacological properties of $\gamma$-aminobutyric acid, glutamate, and aspartate-induced depolarizations in cultured astrocytes. J. Neurosci. 5, 3295-3301.

Kim U. H., Kim J. W., and Rhee S. G. (1989) Phosphorylation of phospholipase C- $\gamma$ by cAMP-dependent protein kinase. J. Biol. Chem. 264, 20169-20170.

Kimelberg H. K., Bowman C. L., and Hirata H. (1986) Anion transport in astrocytes. Ann. NY Acad. Sci. 481, 334-353.

Lapetina E. G., Local J. C., Reep B. R., and Molina y Vedia L. (1989) A ras-related protein in phosphorylated and tranlocated by agonists that increase cAMP levels in human platelets. Proc. Natl. Acad. Sci. USA 86, 3131-3134.
Laufer R. and Changeux J. (1989) Calcitonin gene-related peptide and cyclic AMP stimulate phosphoinositide turnover in skeletal muscle cells. J. Biol. Chem. 264, 2683-2689.

Lazarowski E. R. and Lapetina E. G. (1989) Activation of platelet phospholipase $C$ by fluoride is inhibited by cyclic AMP. Biochem. Biophys. Res. Commun. 158, 440-444.

Lerea K. M., Glomset J. A., and Krebs E. G. (1987) Agents that elevate cAMP levels in platelets decrease thrombin binding. $J$. Biol. Chem. 262, 282-288.

Madison J. M. and Brown J. K. (1988) Differential inhibitory effects of forskolin, isoproterenol, and dibutyryl cyclic adenosine monophosphate on phosphoinositide hydrolysis in canine tracheal smooth muscle. J. Clin. Invest. 82, 1462-1465.

McCarthy K. D. and de Vellis J. (1978) Alpha-adrenergic receptor modulation of beta-adrenergic, adenosine, and prostaglandin $E_{1}$ increased adenosine 3':5'-cyclic monophosphate levels in primary cultures of astrocytes. J. Cyclic Nucleotide Res. 4, 15-26.

Paris S. and Pouyssegur J. (1987) Further evidence for a phospholipase C-coupled $\mathrm{G}$ protein in hamster fibroblasts. Induction of inositol phosphate formation by fluoroaluminate and vanadate and inhibition by pertussis toxin. J. Biol. Chem. 262, 1970-1976.

Pearce B., Albrecht J., Morrow C., and Murphy S. (1986a) Astrocyte glutamate receptor activation promotes inositol phospholipid turnover and calcium flux. Neurosci. Lett. 72, 335-340.

Pearce B., Morrow C., and Murphy S. (1986b) Receptor-mediated inositol phospholipid hydrolysis in astrocytes. Eur. J. Pharmacol. 121, 231-243.

Pearce B., Morrow C., and Murphy S. (1988) Characteristics of phorbol ester- and agonist-induced down-regulation of astrocytes coupled to inositol phospholipid metabolism. J. Neurochem. 50, 936-944.

Portzehl H., Caldwell P. C., and Reugg J. C. (1964) The dependence of contraction and relaxation of muscle fibers from the crab Maia squinado on the internal concentration of free calcium ions. Biochim. Biophys. Acta 79, 581-591.

Puurunen J., Lohse M. J., and Schwabe U. (1987) Interactions between intracellular cyclic AMP and agonist-induced inositol phospholipid breakdown in isolated gastric mucosal cells of the rat. Naunyn Schmiedebergs Arch. Pharmacol. 336, 471-477.

Ritchie T., Cole R., Kim H. S., de Vellis J., and Noble E. P. (1987) Inositol phospholipid hydrolysis in cultured astrocytes and oligodendrocytes. Life Sci. 41, 31-39.

Robertson P. L. and Goldstein G. W. (1988) Heparin inhibits the growth of astrocytes in vitro. Brain Res. 447, 341-345.

Robertson P. L., Markovac J., Datta S. C., and Goldstein G. W. (1988) Transforming growth factor beta stimulates phosphoinositol metabolism and translocation of protein kinase $C$ in cultured astrocytes. Neurosci. Lett. 93, 107-113.

Seamon K. B. and Daly J. W. (1986) Forskolin: its biological and chemical properties. Adv. Cyclic Nucleotide Protein Phosphorylation Res. 20, 1-150.

Shain W., Madelian V., Martin D. L., Kimelberg H. K., Perrone M., and Lepore R. (1986) Activation of $\beta$-adrenergic receptors stimulates release of an inhibitory transmitter from astrocytes. $J$. Neurochem. 46, 1298-1303.

Takenawa T., Ishitoya J., and Nagai Y. (1986) Inhibitory effect of prostaglandin $E_{2}$, forskolin, and dibutyryl cAMP on arachidonic acid release and inositol phospholipid metabolism in guinea pig neutrophils. J. Biol. Chem. 261, 1092-1098.

Van Calker D., Löffler F., and Hamprecht B. (1983) Corticotropin peptides and melanotropins elevate the level of adenosine $3^{\prime}: 5^{\prime}$ cyclic monophosphate in cultured murine brain cells. $\mathrm{J}$. Neurochem. 40, 418-427.

Windebank K. P., Abraham R. T., Powis G., Oisen R. A., Barna T. J., and Leibson P. J. (1988) Signal transduction during human natural killer cell activation: inositol phosphate generation and regulation by cyclic AMP. J. Immunol. 141, 3951-3957.

Yada Y., Nagao S., Okano Y., and Nozawa Y. (1989) Inhibition by cyclic AMP of guanine nucleotide-induced activation of phosphoinositide-specific phospholipase $\mathrm{C}$ in human platelets. FEBS Lett. 242, 368-372. 